\title{
RELATIONSHIPS BETWEEN OTOLITH DIMENSIONS AND BODY GROWTH OF NORTH AFRICAN CATFISH Clarias gariepinus (Burchell, 1822) FROM THE UPPER BASIN OF THE SAKARYA RIVER, TURKEY
}

\author{
Savaş Yılmaz ${ }^{*}$, Özgür Emiroğlu², Sadi Aksu ${ }^{3}$, Sercan Başkurt², Nazmi Polat ${ }^{1}$
}

\begin{abstract}
${ }^{1}$ Department of Biology, Faculty of Arts and Science, Ondokuz Mayıs University, Samsun, Turkey ${ }^{2}$ Department of Biology, Faculty of Arts and Science, Eskişehir Osmangazi University, Eskişehir, Turkey ${ }^{3}$ Vocational School of Health Services, Eskişehir Osmangazi University, Eskişehir, Turkey

*Corresponding Author, Email: savas.yilmaz@omu.edu.tr
\end{abstract}

\section{ARTICLE INFO}

Received: 20 October 2017

Received in revised form: 4 October 2018

Accepted: 15 October 2018

Online first: 22 January 2019

\begin{abstract}
The relationships between otolith size and body length of North African catfish Clarias gariepinus (Burchell, 1822), collected from Sakaryabaşı (the main spring area of the Sakarya River) between July 2014 and November 2014, were examined. Length-weight relationship was also calculated for overall specimens. The wild fish were captured by electrofishing using SAMUS 725MP. A total of 132 individuals ranging from 13.6 to $59.0 \mathrm{~cm}$ in total length and from 15.9 to $1755.0 \mathrm{~g}$ in weight were sampled. The lagenar otolith (asteriscus) length and height, and the utricular otolith (lapillus) length and width were recorded for each fish. The relationships between otolith measurements and fish somatic growth were described by a non-linear function (power model). The $t$ test revealed no considerable differences in these relationships between left and right otoliths. The ANCOVA test on the relationships between total length and otolith variables did not show significant differences between females and males. All relationships were highly significant and the mean percent prediction errors were less than $7 \%$. The results showed that otolith growth reflected body growth.
\end{abstract}

Yılmaz, S., Emiroğlu, Ö., Aksu, S., Başkurt, S., Polat, N. (2019): Relationships between otolith dimensions and body growth of North African catfish Clarias gariepinus (Burchell, 1822) collected from the upper basin of the Sakarya River, Turkey. Croatian Journal of Fisheries, 77, 57-62. DOI: 10.2478/cjf-2019-0006.

\section{INTRODUCTION}

North African catfish Clarias gariepinus (Burchell, 1822) is a member of the family Clariidae, the air-breathing catfishes (Nelson, 2006). Its native range covers most of
Africa and small parts of Asia (Jordan, Israel, Lebanon, Syria and Southern Turkey) (Froese and Pauly, 2016). This fish has many different habitats such as natural lakes and dam lakes, rivers, shallow swamps, seasonal floodplains and some estuaries (Weyl et al., 2016). It is an omnivorous 
species feeding on fruits and seeds, all kinds of aquatic invertebrates and small vertebrates, small mammals and even plankton (Bruton, 1979; Yalçın et al., 2001). In Turkey, $C$. gariepinus is naturally found in the basins of the Asi, Seyhan, Ceyhan, Göksu Rivers (Geldiay and Balık, 2007; Emiroğlu, 2011). Furthermore, it was translocated to the Aksu and Sakarya Rivers (Turan and Turan, 2016).

Otoliths (ear stones) are calcareous structures that are located in the head of fish and mediate both hearing and balance (Quist et al., 2012). Osteichthyan species have three pairs of otoliths: the sagittae, lapilli and asterisci (Secor et al., 1992). The otoliths differ in size and shape (Wright et al., 2002). The sagitta is the biggest of the three otolith types in nonostariophysian fishes; however, in ostariophysian teleosts (e.g. Cypriniformes and Siluriformes), the asteriscus and/or lapillus are much larger than the fragile and arrow-like sagitta (SchulzMirbach and Plath, 2012). The sagitta is the otolith with the largest morphological variation (Tuset et al., 2008). The other two otolith types also show remarkable differences among fish species (Assis, 2003, 2005; Yilmaz et al., 2015).

Taxonomic and biometric studies on otoliths aim to identify fish species consumed by piscivorous animals and to reconstruct their size and mass (Battaglia et al., 2015). For these purposes, otolith identification guides and atlases have been published (e.g. Campana, 2004; Tuset et al., 2008; Sadighzadeh et al., 2012) and otolith sizefish length relationships have also been determined (e.g. Waessle et al., 2003; Longenecker, 2008; Battaglia et al., 2010; Skeljo and Ferri, 2012; Battaglia et al., 2015; Giménez et al., 2016). Similarly, it is possible to reconstruct the paleoenvironments and the paleofaunas with the otoliths retrieved from archaeological and paleontological finds (Nolf, 1995; Schulz-Mirbach and Reichenbacher, 2006). Although C. gariepinus is an efficient predator fish, it is an important food item for some piscivorous animals such as fishes (e.g. Hydrocynus vittatus), birds (e.g. Haliaeetus vocifer) and crocodiles (e.g. Crocodylus niloticus) (Froese and Pauly, 2016). The reconstruction of the actual size and mass of this prey fish from the otoliths found in stomach contents or feces of these fish predators may provide significant contributions to the understanding of the feeding ecology of the before mentioned predators. However, studies of the relationship between otolith size and fish length are unavailable for North African catfish. Therefore, the main objective of this paper is to describe the relationships between otolith size and somatic growth, and between body weight and length of $C$. gariepinus inhabiting the upper basin of the Sakarya River in Turkey. Additionally, the present study provides the first information on the morphological characteristics of the lagenar and utricular otoliths of North African catfish.

\section{MATERIAL AND METHODS}

The wild fish were collected from Sakaryabaşı at monthly intervals between July 2014 and November 2014. Sakaryabaşı, located $5 \mathrm{~km}$ south-east of Çifteler district of Eskişehir province in the central Anatolia region of Turkey, is the main spring area of the Sakarya River. Of the three springs in this area, two are cold water and one is hot water. The water temperature ranges from 16 to $24^{\circ} \mathrm{C}$ throughout the year (Emiroğlu, 2011). The specimens were captured by electrofishing using SAMUS 725MP. A total of 132 C. gariepinus individuals ( 74 females, 54 males and 4 unidentified sexes) were captured during the sampling period. Total length (TL) and weight (W) of each fish was recorded to the nearest $0.1 \mathrm{~cm}$ and $0.01 \mathrm{~g}$, respectively. Sex was determined by macroscopic examination of gonads. The lagenar (asteriscus) and the utricular (lapillus) otoliths were removed, cleaned and stored dry in eppendorf tubes. All otoliths were photographed on the proximal surface (for asterisci) and ventral surface (for lapilli) with a Leica DF295 digital camera. The asteriscus length ( $A L)$, asteriscus height (AH), lapillus length (LL) and lapillus width (LW) were measured to the nearest 0.001 $\mathrm{mm}$ using Leica Application Suit ver. 3.8 Imaging Software. Otolith length for the asteriscus and lapillus was defined as the greatest distance between anterior and posterior margin. Otolith height for the asteriscus was defined as the greatest distance between dorsal and ventral edge. Otolith width for the lapillus was described as the greatest distance from lateral to medial margin (Yilmaz et al., 2015) (Fig. 1). The relationships between otolith dimensions and fish length were established using non-linear $\left(y=a x^{b}\right)$ regression model for the following parameters: TL-AL, TL-AH, TL-LL and TL-LW. These equations were generated separately for both left and right otoliths of each sex, and the $t$ test was used to compare regression coefficients (Battaglia et al., 2015). Similarly, the sex-linked changes in the above-mentioned relations were examined with the analysis of covariance (ANCOVA), sex as the main factor and TL as the covariate (Zar, 1999). When significant differences $(P<0.05)$ were not found, the $H_{0}$ hypotheses $\left(b_{\text {left }}=b_{\text {right }}\right.$ and $\left.b_{\text {female }}=b_{\text {male }}\right)$ were accepted. Where regression coefficients did not differ statistically, a single regression was reported for each variable by choosing the right otolith measurements and by pooling the data of both sexes. The $t$ test was used to compare the slopes with a value corresponding to isometry (Zar, 1999). The strength of each relation was evaluated by both the $r^{2}$ value and by calculating the mean percent prediction error. The mean percent prediction error for regression is average of the percent prediction error values calculated for all individuals. The percent prediction error (\%PE) for an individual is obtained by using the following formula (Smith, 1980):

$$
\% \mathrm{PE}=\frac{\left|\mathrm{X}_{\text {observed }}-\mathrm{X}_{\text {predicted }}\right|}{\mathrm{X}_{\text {predicted }}} \times 100
$$


The difference between observed and predicted fish size value was checked for each otolith measurement by using $t$ test, and the analysis of variance was used to compare the differences between the mean PE\% values of the otolith parameters.

Length-weight relation (LWR) of this species was also determined by commonly used equation (Neumann et al., 2012):

$$
W=a L^{b}
$$

where $\mathrm{W}$ is weight, $\mathrm{L}$ is total length, $a$ is intercept and $b$ is slope. Parameters $a$ and $b$ were estimated by linear regression of logarithmic transformed length-weight data. The slopes of LWRs of females and males were compared by the ANCOVA test. Whether the growth of fish is isometric $(b=3)$ or allometric $(b<3$ or $b>3)$ was checked by the $t$ test (Zar, 1999).

\section{RESULTS}

The lapillus of $C$. gariepinus is bigger than the asteriscus. The dorsal surface of the lapillus is slightly rough. There is a bump in the middle part of the ventral surface. The asteriscus is disc-shaped. Its distal (lateral) surface is smooth and slightly convex. Proximal (medial) surface is slightly concave and has a horse-shoe shaped structure (Fig. 1).

In the analysis of otolith morphometric variables against $\mathrm{TL}$, no significant difference was found between the coefficients of the equations obtained for right and left otoliths in each sex ( $t$ test; TL-AL, $t=1.09, P=0.282$; TL$\mathrm{AH}, t=0.24, P=0.814 ; \mathrm{TL}-\mathrm{LL}, t=1.07, P=0.287$; TL-LW, $t=$ 1.11, $P=0.271$ for females and TL-AL, $t=0.00, P=1.000$; $\mathrm{TL}-\mathrm{AH}, t=0.98, P=0.331 ; \mathrm{TL}-\mathrm{LL}, \mathrm{t}=0.79, P=0.430 ; \mathrm{TL}-\mathrm{LW}$, $t=0.64, P=0.524$ for males). Therefore, the right otoliths were chosen for subsequent analysis. The ANCOVA test showed that there was no statistical difference between slopes of females and males for TL-AL $(F=0.05, P=0.825)$, TL-AH $(F=3.37, P=0.069)$, TL-LL $(F=2.73, P=0.101)$, and TL-LW $(F=0.00, P=0.996)$. Thus, data of both sexes were pooled. The descriptive statistics of fish and otolith parameters are given in Table 1.

All regressions were highly significant $(P<0.001)$. The coefficient of determination $\left(r^{2}\right)$ ranged from 0.880 to 0.928 and the regression models explained more than $87 \%$ of the variance. The lapillus length had the highest coefficient of determination among the lapillus biometrics, while the asteriscus length had the highest coefficient of determination among the asteriscus measurements (Table 2). The relationships of otolith size against fish body length were negative allometric ( $t$ test; TL-AL, $t=-6.93$;

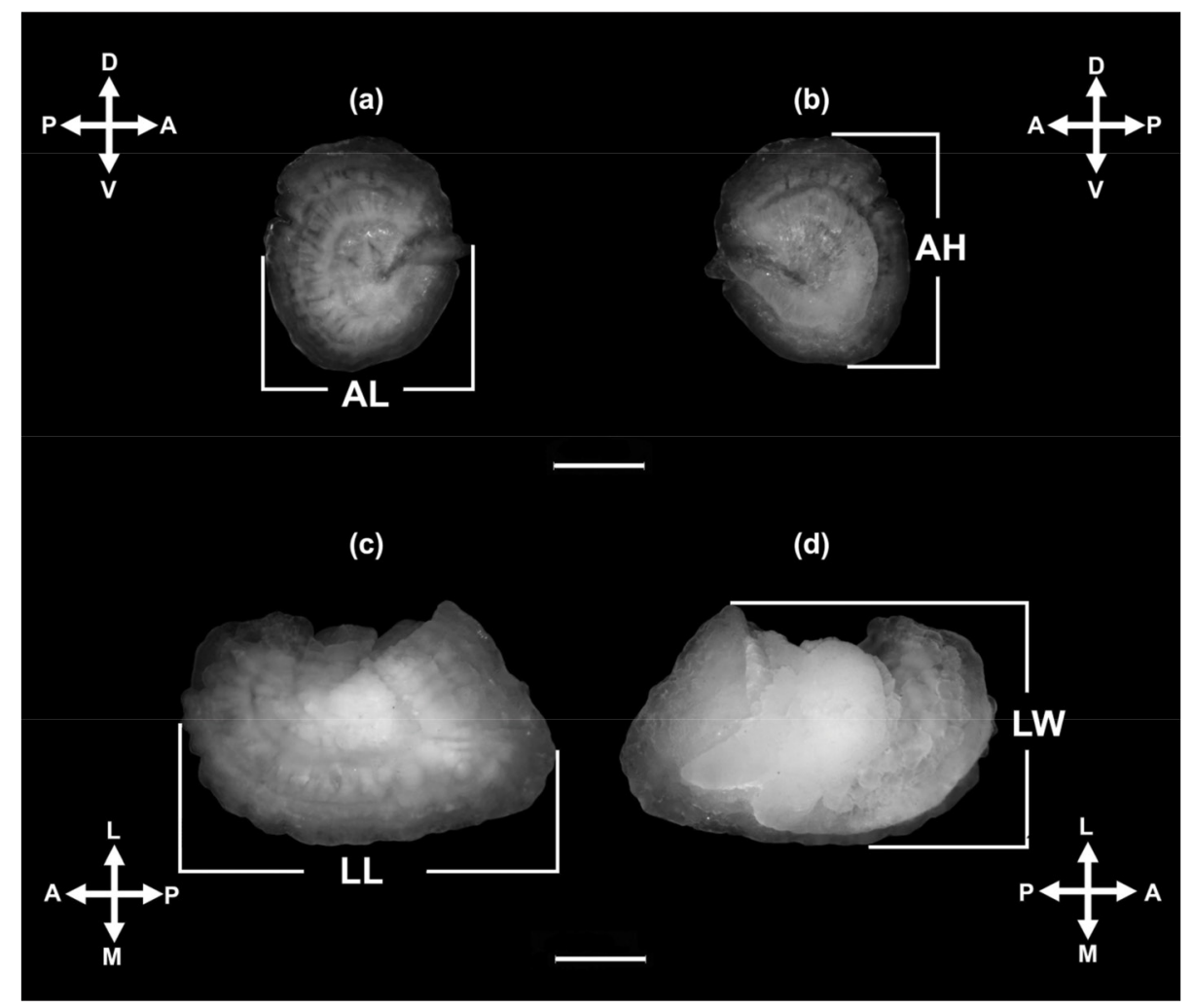

Fig 1. The lagenar (asteriscus) and utricular (lapillus) otoliths of North African catfish Clarias gariepinus collected from Sakaryabaşı, the upper basin of the Sakarya River: The distal (a) and proximal (b) views of the right asteriscus, and the dorsal (c) and ventral (d) views of the right lapillus ( $A L$, asteriscus length; $A H$, asteriscus height; LL, lapillus length; LW, lapillus width; $A$, anterior; $P$, posterior; $D$, dorsal; V, ventral; L, lateral; $M$, medial), Scale bar $=1 \mathrm{~mm}$ 
Table 1. Descriptive statistics of Clarias gariepinus and their otoliths collected from Sakaryabaşı, the upper basin of the Sakarya River, Turkey

\begin{tabular}{lccc}
\hline \hline Measure & $n$ & Mean \pm SD & Min-Max \\
\hline Fish length (cm) & 132 & $31.59 \pm 7.17$ & $13.6-59.0$ \\
Fish weight (g) & 132 & $244.4 \pm 232.8$ & $15.9-1755.0$ \\
Asteriscus length (mm) & 120 & $2.523 \pm 0.433$ & $1.157-3.758$ \\
Asteriscus heigth (mm) & 120 & $2.670 \pm 0.479$ & $1.321-3.922$ \\
Lapillus length (mm) & 127 & $4.523 \pm 0.807$ & $1.321-3.922$ \\
Lapillus width (mm) & 127 & $2.901 \pm 0.538$ & $1.348-4.327$ \\
\hline \hline
\end{tabular}

$n$, sample size; SD, standard deviation; Min-Max, minimum and maximum values observed

$\mathrm{TL}-\mathrm{AH}, t=-5.10 ; \mathrm{TL}-\mathrm{LL}, t=-9.80 ; \mathrm{TLLW}, t=-6.73 ; \mathrm{P}<0.001)$, indicating that the growth of otolith is relatively slower than fish size.

The mean percent prediction errors ranged from 4.88 to 6.25 (Table 2). The lapillus length had the lowest value of mean \%PE. For each otolith variable, there was no considerable difference between observed and predicted TL values ( $t$ test; AL, $t=0.02, P=0.985, d f=237 ; \mathrm{AH}, t$ $=-0.11, P=0.912, d f=237 ; \mathrm{LL}, t=0.10, d f=251 ; \mathrm{LW}$, $t=0.00, P=0.997, d f=251)$. Non-statistical significant difference was determined in the mean \%PE values of the otolith parameters (ANOVA, $F=1.94, P=0.122$ ).

The length-weight relationship of this species was found as $\mathrm{W}=0.0061 \mathrm{~L}^{3.016}$ for all specimens $(n=132$, SE $(b)=$ $\left.0.039, r^{2}=0.979\right)$. No significant difference was observed in slopes of LWRs of females and males (ANCOVA, $F=$ $0.76, P=0.376)$. The parameter $b$ of LWR was not different from 3 ( $t$ test, $t=0.41, P=0.682$ ). This result showed an isometric growth.

\section{DISCUSSION}

To our knowledge, this study is the first application that defines the relationships between otolith size and body length of North African catfish. The results from this study indicated that there were no significant differences between right and left otoliths and between female and male otoliths. These findings are consistent with the observations of some authors (Jawad and Al-Mamry, 2012; Félix et al., 2013; Zengin et al., 2015; Dehghani et al., 2016), but differ from results of some other studies (Hunt, 1992; Kontas and Bostanci, 2015). Campana (1990) stated that otolith size - fish size relations may change among populations or fish species with different growth rates.

As a result of analysis of morphometric relations, it was concluded that the lapillus length and asteriscus length are better indicators of fish somatic growth than other measurements of otoliths. When lapillus length is used, the regression explained over $92 \%$ of the data variation.

Table 2. The nonlinear (power) relationships between otolith dimensions and body size, and the mean percent prediction errors of each regression for Clarias gariepinus obtained from Sakaryabaşı, the upper basin of the Sakarya River, Turkey

\begin{tabular}{|c|c|c|c|c|c|c|c|}
\hline \multirow{2}{*}{ Relationship } & \multirow{2}{*}{$n$} & \multicolumn{3}{|c|}{ Regression parameters } & \multirow{2}{*}{$\begin{array}{l}\text { Observed TL } \\
\text { (Mean } \pm \text { SD) }\end{array}$} & \multirow{2}{*}{$\begin{array}{l}\text { Predicted TL } \\
\text { (Mean } \pm \text { SD) }\end{array}$} & \multirow[b]{2}{*}{$\% \mathrm{PE} \pm \mathrm{SD}$} \\
\hline & & $a \pm \mathrm{SE}$ & $b \pm \mathrm{SE}$ & $r^{2}$ & & & \\
\hline TL vs. AL & 120 & $0.153 \pm 0.014$ & $0.813 \pm 0.027$ & 0.887 & $31.57 \pm 6.68$ & $31.55 \pm 6.66$ & $5.73 \pm 4.45$ \\
\hline TL vs. AH & 120 & $0.141 \pm 0.014$ & $0.852 \pm 0.029$ & 0.880 & $31.57 \pm 6.68$ & $31.66 \pm 6.66$ & $5.73 \pm 4.45$ \\
\hline TL vs. LL & 127 & $0.284 \pm 0.020$ & $0.804 \pm 0.020$ & 0.928 & $31.51 \pm 7.08$ & $31.42 \pm 6.98$ & $4.88 \pm 3.62$ \\
\hline TL vs. LW & 127 & $0.169 \pm 0.015$ & $0.825 \pm 0.026$ & 0.887 & $31.51 \pm 7.08$ & $31.51 \pm 7.07$ & $6.25 \pm 4.61$ \\
\hline
\end{tabular}

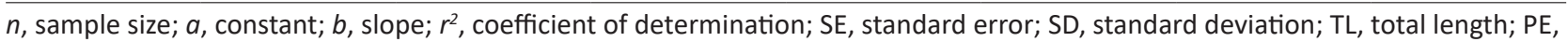
percent prediction error 
When asteriscus length is used, the regression explained more than $88 \%$ of the data variation. According to the length-weight relationship, isometric growth was recorded for $C$. gariepinus inhabiting Sakaryabaşı. The same result was also reported by Özcan (2008). On the other hand, positive or negative allometric growth was detected by some authors (Keyombe et al., 2015; Adebola et al., 2016). It is appropriate to use the regressions presented in this study within the fish size range limits reported, in order to avoid errors in length and weight estimation. For better understanding of the otolith growth of $C$. gariepinus, it is necessary to examine the otolith morphology and morphometry in populations inhabiting different habitats of this species. It is hoped that the results of the present study will be useful for researchers examining food habits of the potential predators of North African catfish.

\section{ACKNOWLEDGEMENTS}

The authors thank M. M. Sakallı and C. Şimşek for their help during the laboratory process.

\section{SAŽETAK}

\section{ODNOSI DIMENZIJA OTOLITA I RASTA TIJELA SJEVERNOAFRIČKOG SOMA Clarias gariepinus (Burchell, 1822) IZ GORNJEG SLIVA RIJEKE SA- KARYA, TURSKA}

U radu su istraživani odnosi između veličine otolita i dužine tijela sjevernoafričkog soma Clarias gariepinus (Burchell, 1822) uzorkovanih iz vodotoka Sakaryabaşı (glavno područje izvora rijeke Sakarya) u razdoblju od srpnja do studenog 2014. godine. Također, izračunat je i dužinskomaseni odnos za ukupan uzorak. Divlje ribe su ulovljene elektroribolovom koristeći elektroagregat SAMUS 725MP. Analizirano je ukupno 132 jedinke totalne dužine od 13,6 $-59,0 \mathrm{~cm}$ i mase raspona 15,9-1755,0 g. Svakoj ribi je zabilježena dužina i visina lagenarskog (asteriscus) otolita te dužina i širina utrikularnog (lapillus) otolita. Odnos između izmjerenih otolitnih vrijednosti i somatskog rasta riba opisan je nelinearnom funkcijom. T test nije ukazao na značajne razlike u navedenim odnosima između lijevih i desnih otolita. ANCOVA test odnosa između totalne dužine i otolitnih varijabli nije ukazao na značajne razlike između ženki i mužjaka riba. Svi odnosi su bili visoko značajni, a prosječna pogreška predviđanja postotka bila je manja od 7\%. Rezultati istraživanja su indicirali da otolitni rast odražava rast tijela.

Ključne riječi: Biometrija otolita, lapillus, asteriscus, dužinsko-maseni odnos, Sakaryabaşı

\section{REFERENCES}

Adebola, O. T., Bello-Olusoji, O. A., Fagbenro, A. O., Sabejeje, T. A. (2016): Length weight relationship and condition factor of four commercially important fish species at ERO Reservoir, Ekiti State, Nigeria. International Journal of Innovative Research and Development, 5, 324-328.

Assis, C. A. (2003): The lagenar otoliths of teleosts: their morphology and its application in species identification, phylogeny and systematics. Journal of Fish Biology, 62, 1268-1295.

Assis, C. A. (2005): The utricular otoliths, lapilli, of teleosts: their morphology and relevance for species identification and systematics studies. Scientia Marina, 69, 259-273.

Battaglia, P., Malara, D., Romeo, T., Andaloro, F. (2010): Relationships between otolith size and fish size in some mesopelagic and bathypelagic species from the Mediterranean Sea (Strait of Messina, Italy). Scientia Marina, 74, 605-612.

Battaglia, P., Malara, D., Ammendolia, G., Romeo, T., Andaloro, F. (2015): Relationships between otolith size and fish length in some mesopelagic teleosts (Myctophidae, Paralepididae, Phosichthyidae and Stomiidae). Journal of Fish Biology, 87, 774-782.

Bruton, M. N. (1979): The food and feeding behaviour of Clarias gariepinus (Pisces: Clariidae) in Lake Sibaya, South Africa, with emphasis on its role as a predator of cichlids. The Transactions of the Zoological Society of London, 35, 47-114.

Campana, S. E. (1990): How reliable are growth backcalculations based on otoliths? Canadian Journal of Fisheries and Aquatic Sciences, 47, 2219-2227.

Campana, S. E. (2004): Photographic atlas of fish otoliths of the Northwest Atlantic Ocean. Ottawa (Canada), NRC Research Press. 284.

Dehghani, M., Kamrani, E., Salarpouri, A., Sharifian, S. (2016): Otolith dimensions (length, width), otolith weight and fish length of Sardinella sindensis (Day, 1878), as index for environmental studies, Persian Gulf, Iran. Marine Biodiversity Records, 9, 44.

Emiroğlu, Ö. (2011): Alien fish species in upper Sakarya River and their distribution. African Journal of Biotechnology, 10, 16674-16681.

Félix, V. R., Martínez-Pérez, J. A., Molina, J. R., Zuňiga, R. E. Q., López, J. F. (2013): Morphology and morphometric relationships of the sagitta of Diapterus auratus (Perciformes: Gerreidae) from Veracruz, Mexico. International Journal of Tropical Biology and Conservation, 6, 139-147.

Froese, R., Pauly D. (2016): Fishbase. Available from www. fishbase.org [cited 2016 January 21].

Geldiay, R., Balık, S. (2007). Türkiye tatısu balıkları. Bornova (İzmir), Ege Üniversitesi Su Ürünleri Fakültesi Yayınları. 644. 
Giménez, J., Manjabacas, A., Tuset, V. M., Lombarte, A. (2016): Relationships between otolith and fish size from Mediterranean and north-eastern Atlantic species to be used in predator-prey studies. Journal of Fish Biology, 89, 2195-2202.

Hunt, J. J. (1992): Morphological characteristics of otoliths for selected fish in the Northwest Atlantic. Journal of Northwest Atlantic Fishery Science, 13, 63-75.

Jawad, L. A., Al-Mamry, J. (2012): Relationship between fish length and otolith dimensions in the carangid fish (Carangoides coeruleopinnatus Rüppell, 1830) collected from the Sea of Oman. Journal of Fisheries Sciences.com, 6, 203-208.

Keyombe, J. L., Waithaka, E., Obegi, B. (2015): Lengthweight relationship and condition factor of Clarias gariepinus in Lake Naivasha, Kenya. International Journal of Fisheries and Aquatic Studies, 2, 382-385.

Kontas, S., Bostanci, D. (2015): Morphological and biometrical characteristics on otolith of Barbus tauricus (Kessler, 1877) on light and scanning electron microscope. International Journal of Morphology, 33, 1380-1385.

Longenecker, K. (2008): Relationships between otolith size and body size for Hawaiian reef fishes. Pacific Science, 62, 533-539.

Nelson, J. S. (2006): Fishes of the world. New Jersey (USA), John Wiley and Sons. 601.

Neumann, R. M., Guy, C. S., Willis, D. W. (2012): Length, weight, and associated indices. pp. 637-676. In: Zale, A. V., Parrish, D. L., Sutton T. M. (eds), Fisheries techniques. American Fisheries Society, Bethesda, Maryland, USA, 1069.

Nolf, D. (1995): Studies on fossil otoliths-the state of the art, 513-544. In: Secor, D. H., Dean, J. M., Campana S. E. (eds), Recent developments in fish otolith research. University of South Carolina Press, Columbia, SC, 730.

Özcan, G. (2008): Length-weight relationships of five freshwater fish species from the Hatay province, Turkey. Journal of Fisheries Sciences.com, 2, 51-53.

Quist, M. C., Pegg, M. A., DeVries, D. R. (2012): Age and growth, 677-731. In: Zale, A., Parrish, D., Sutton, T. (eds), Fisheries Techniques. American Fisheries Society, Bethesda, Maryland, USA. 1009.

Sadighzadeh, Z., Tuset, V. M., Dadpour, M. R., OteroFerrer, J. L., Lombarte, A. (2012): Otolith atlas from the Persian Gulf and Oman Sea fishes. Germany, Lambert Academic Publishing. 72.

Schulz-Mirbach, T., Plath, M. (2012): All good things come in threes-species delimitation through shape analysis of saccular, lagenar and utricular otoliths. Marine and Freshwater Research, 63, 934-940.
Schulz-Mirbach, T., Reichenbacher, B. (2006): Reconstruction of Oligocene and Neogene freshwater fish faunas-an actualistic study on cypriniform otoliths. Acta Palaeontologica Polonica, 51, 283-304.

Secor, D. H., Dean, J. M., Laban, E. H. (1992): Otolith removal and preparation for microstructural examination, 1957. In: Stevenson, D. K., Campana, S. E. (eds), Otolith microstructure examination and analysis. Canadian Special Publication of Fisheries and Aquatic Sciences, Ottawa, Canada, 126.

Škeljo, F., Ferri, J. (2012): The use of otolith shape and morphometry for identification and size-estimation of five wrasse species in predator-prey studies. Journal of Applied Ichthyology, 28, 524-530.

Smith, R. J. (1980): Rethinking allometry. Journal of Theoretical Biology, 87, 97-111.

Turan, F., Turan, C. (2016): Natural and non-natural distribution of African catfish Clarias griepinus (Burchell, 1822) in Turkey. Journal of Limnology and Freshwater Fisheries Research, 2, 173-177.

Tuset, V. M., Lombarte, A., Assis, C. A. (2008): Otolith atlas for the western Mediterranean, north and central eastern Atlantic. Scientia Marina, 72, 7-198.

Waessle, J. A, Lasta, C. A., Favero, M. (2003): Otolith morphology and body size relationships for juvenile Sciaenidae in the Rio de la Plata estuary (35-36 $\left.{ }^{\circ} \mathrm{S}\right)$. Scientia Marina, 67, 233-240.

Weyl, O. L. F., Daga, V. S., Ellender, B. R., Vitulet, J. R. S. (2016): A review of Clarias gariepinus invasions in Brazil and South Africa. Journal of Fish Biology, 89, 386-402.

Wright, P. J., Panfili, J., Morales-Nin, B., Geffen, A. J. (2002): Types of calcified structures, 31-56. In: Panfili, J., Pontual, H (de)., Troadec, H., Wright, P. J. (eds), Manual of fish sclerochronology. Ifremer-IRD coedition, Brest, France, 464.

Yalçın, S., Akyurt, İ., Solak, K. (2001): Stomach contents of the catfish Clarias gariepinus (Burchell, 1822) in the River Asi (Turkey). Turkish Journal of Zoology, 25, 461468.

Yilmaz, S., Yazicioglu, O., Yazici, R., Polat, N. (2015): Relationships between fish length and otolith size for five cyprinid species from Lake Ladik, Turkey. Turkish Journal of Zoology, 39, 438-446.

Zar, J. H. (1999): Biostatistical Analysis. New Jersey (USA), Prentice-Hall. 663.

Zengin, M., Saygın, S., Polat, N. (2015): Otolith shape analyses and dimensions of the Anchovy Engraulis encrasicolus L. in the Black and Marmara Seas. Sains Malaysiana, 44, 657-662. 